\title{
Furfural-based Resin for Modifying Birch Wood Properties
}

\author{
Marzieh Sharifat, ${ }^{\mathrm{a}}$ Davood Efhamisisi, ${ }^{\mathrm{b}, *}$ Marie-France Thevenon, ${ }^{\mathrm{c}, \mathrm{d}}$ Asghar Tarmian, ${ }^{\mathrm{e}}$ \\ and Mehdi Jonoobi ${ }^{\mathrm{f}}$
}

Furfural $(F)$ cannot be easily polymerized like furfuryl alcohol, but it is an aldehyde that can react with urea $(U)$ to make a polymeric network. The possibility of preparing $\mathrm{F} / \mathrm{U}$ polymer along with an acidic catalyzer (maleic anhydride; M) was evaluated as a means to improve some selected properties of birch (Betula pendula) wood. The $\mathrm{F}+\mathrm{U} / \mathrm{M}$ resin was introduced into the wood with a double treatment technology. The first step involved dilution of $\mathrm{F}$ in water and methanol, and the second step was immersion in a U/M aqueous solution. The color of treated wood was darkened after resin curing from brown to a spectrum of black depending on the amount of loaded resin. The 60 to $80 \%$ of materials were converted to a non-leachable polymer based on the different formulations. The water absorption and volumetric swelling of the treated samples decreased with an increase in weight percent gain (WPG). The analysis of mechanical strength showed that treatment with $\mathrm{F}+\mathrm{U} / \mathrm{M}$ reduced to some extent the hardness and the impact bending of wood, while modulus of rupture, modulus of elasticity, and compression parallel to the grain with WPG were increased. The exposure of the samples to the accelerated weathering showed noticeable changes in color and roughness.

Keywords: Furfural; Urea; Physical-mechanical properties; Weathering; Birch

Contact information: a: Faculty of Natural Resources, University of Tehran, Karaj, Iran; $b$ : Department of Wood and Paper Sciences and Technology, Faculty of Natural Resources, University of Tehran; c: UR BioWooEB, CIRAD, Montpellier, France; d: BioWooEB, Université de Montpellier, CIRAD, Montpellier, France; e: Department of Wood and Paper Sciences and Technology, Faculty of Natural Resources, University of Tehran; and f: Department of Wood and Paper Sciences and Technology, Faculty of Natural Resources, University of Tehran; *Corresponding author: efhami@ut.ac.ir

\section{INTRODUCTION}

The impregnation of wood with various monomers and resins, and then their conversion into a polymer in situ, is one of the approaches to improve wood properties (Hill 2006). Some materials that have been used in commercial systems for wood impregnation include vinyl monomers (Li 2011), furfuryl alcohol (Buchelt et al. 2012), amino and phenolic resins (Gindl et al. 2003), and silicone compounds (Mai and Militz 2004). In-situ polymerization of monomer or resin in wood by one of the common methods, such as curing, adding a hardener, or with radiation, leads to a new product called a wood polymer. Depending on the polarity and size of molecules used/added, the polymer can be positioned in cell walls, cell cavities, or both, thereby affecting the intrinsic properties of the wood (Keyoumu et al. 2007).

The treatment of wood with furfuryl alcohol (FA) monomers is called wood furfurylation (Gérardin 2016). Some physico-mechanical properties and biological durability of furfurylated wood are enhanced by this technology (Esteves et al. 2011; Abdolzadeh et al. 2013; Dong et al. 2014; Li et al. 2020; Thygesen et al. 2010). 
Furfurylated wood is currently manufactured in Europe and supplied to the world markets under the trade name Kebony® (Larnøy et al. 2008; Esteves et al. 2011; Mantanis 2017). Furfurylated wood has light to dark brown colors, depending on the amount of weight percent gain (WPG) due to the loading of FA resin. Furfuryl alcohol, as well as acid catalyst, buffering agent, and water or ethanol (as solvent) is needed for the wood furfurylation process (Sejati et al. 2017).

Furfuryl alcohol $\left(\mathrm{C}_{5} \mathrm{H}_{6} \mathrm{O}_{2}\right)$ is obtained from hydrogenation of furfural (F). Furfural $\left(\mathrm{C}_{5} \mathrm{H}_{4} \mathrm{O}_{2}\right)$ is an aldehyde and is produced from the dehydration of agricultural waste such as sugarcane bagasse, molasses, barley, corn stems, etc. (Lande et al. 2008). Furfural and its derivatives are widely used in paints and resins, adhesives, plastics, pharmaceuticals, agriculture, oil production, and paper making (Schneider and Phillips 2007a; Sabeti Fard et al. 2014; Ahmadi et al. 2015). An annual equivalent of 5,000 tons of $\mathrm{F}$ is produced from sugar cane bagasse in Iran by the National Behran Oil Company (Sabeti Fard et al. 2014). Furfural alone cannot be used to produce furan resins (Schneider and Phillips 2007b), but it can be hardened with reagents such as urea (U), melamine, phenol, tannin, and lignin (Schneider and Phillips 2007a). A great deal of research has been done on the U-F resins as wood adhesives, and those resins have an old history in the wood industry (Novotny and Johnson 1931). However, the use of these U-F combinations has dropped due to the poor reactivity of $U$ with $F$ as well as to the black color of this resin (Pizzi 2016). Later on, $F$ was used as an additive in common synthetic resin to improve plasticity. Pizzi and Scharfetter (1978) increased the plasticity of tannin-formaldehyde resin by adding small amounts of $\mathrm{F}$ to improve the distribution of stress forces on the glue line. Additionally, partially substituting formaldehyde with $F$ in the synthesis of $U$ formaldehyde resin reduced the formaldehyde emission without affecting the mechanical properties of wood composites (Ghafari et al. 2016). Furfural is toxic in its unreacted form, like formaldehyde, but is not toxic after reaction with urea and formation of a solid resin (Reed and Kwok 2014).

Contrary to many studies that have been reported on wood modification with FA, there are only a few with F. Schneider and Phillips (2007a,b) developed an innovative method for wood modification using U-F resin. They reported two different formulations based on the impregnation method and also the concentration of products that resulted in the different WPG of wood specimens. The dimensional stability and durability of some hardwood and softwood species were improved depending on WPG values.

In the present study, various formulations of U/F were designed to impregnate wood samples, then products were cured into the wood by heating. Some selected physicomechanical properties as well as the weathering resistance of the modified wood were studied.

\section{EXPERIMENTAL}

\section{Materials}

The used wood species was birch (Betula pendula), imported to Iran from Russia. The lumber was air-dried for two months before sampling. The commercial furfural (98.5\%) was supplied by National Behran Oil Company (Tehran, Iran). Solid urea (as reagent, 99.5\%), maleic anhydride (as catalyst, 99\%), and di-sodium tetraborate (as a buffering agent, 99.5\%) were purchased from Chem-Lab Co. (Zedelgem, Belgium). Furfuryl alcohol (98\%) was supplied by Merck Co. (Darmstadt, Germany). For 
convenience, the letters F, U, M, and FA were used as abbreviations for furfural, urea, maleic anhydride, and furfuryl alcohol, respectively.

\section{Methods}

Sampling

The wood samples for various tests were prepared according to the relevant standards (Table 1). Before use for impregnation, the samples were placed in the oven at $103{ }^{\circ} \mathrm{C}$ until mass consistency. Then, the oven dry weight $\left(m_{1}\right)$ and volume $\left(v_{1}\right)$ of each sample were measured.

\section{Table 1. Dimensions of Samples According to Relevant Standards}

\begin{tabular}{|c|c|c|c|c|}
\hline No. & & Test & $\begin{array}{l}\text { Standard } \\
\text { No. }\end{array}$ & $\begin{array}{c}\text { Dimensions of Sample } \\
\text { (Longitudinal } \times \text { Radial } \times \\
\text { Tangential) } \\
\left(\mathrm{mm}^{3}\right)\end{array}$ \\
\hline 1 & (volumetric & $\begin{array}{l}\text { nysical properties } \\
\text { velling and water absorption) }\end{array}$ & $\begin{array}{c}\text { ISO } \\
13061-13 \\
(2016) ; \\
\text { ISO } \\
13061-2 \\
(2014)\end{array}$ & $30 \times 20 \times 20$ \\
\hline 2 & & Leaching & $\begin{array}{l}\text { EN 84 } \\
(2020)\end{array}$ & $50 \times 25 \times 15$ \\
\hline 3 & \multirow{4}{*}{$\begin{array}{l}\text { Mechanical } \\
\text { properties }\end{array}$} & Hardness & $\begin{array}{c}\text { ISO } \\
13061-12 \\
(2014)\end{array}$ & $50 \times 50 \times 50$ \\
\hline 4 & & $\begin{array}{l}\text { Compression } \\
\text { parallel to the grain }\end{array}$ & $\begin{array}{c}\text { ISO } \\
13061-17 \\
(2014)\end{array}$ & $60 \times 20 \times 20$ \\
\hline 5 & & Impact bending & $\begin{array}{c}\text { ISO } \\
13061-10 \\
(2014)\end{array}$ & $300 \times 20 \times 20$ \\
\hline 6 & & $\begin{array}{c}\text { Modulus of rupture and } \\
\text { Modulus of elasticity in } \\
\text { bending }\end{array}$ & $\begin{array}{c}\text { ISO } \\
13061-3 \\
(2014)\end{array}$ & $300 \times 20 \times 20$ \\
\hline 7 & \multicolumn{2}{|r|}{ Weathering test } & $\begin{array}{l}\text { EN 927-6 } \\
\text { (2018) }\end{array}$ & $150 \times 100 \times 18$ \\
\hline
\end{tabular}

Impregnation solutions and treatments

The simultaneous use of furfural and urea, along with acidic catalysts, results in abrupt curing of resin and cannot be used to impregnate wood. Therefore, to prevent this phenomenon, a double treatment process was used (Fig. 1). First, the samples were impregnated with the different concentrations of $\mathrm{F}$ dissolved in water/methanol $(60: 40$ $\mathrm{m} / \mathrm{m}$ ) by empty cell method. The oven-dried samples were placed in the cylinder and a pressure of $0.2 \mathrm{MPa}$ was applied for $30 \mathrm{~min}$. Then, the solution was poured over the samples using higher pressure $(0.6 \mathrm{MPa})$ and applied for $2 \mathrm{~h}$. Finally, the cylinder was drained and a final vacuum of $0.05 \mathrm{MPa}$ was applied for $15 \mathrm{~min}$ before removing the samples. The weight of samples was measured $\left(m_{2}\right)$ to calculate the uptake of solution. In a second step, the aqueous solution of urea and maleic anhydride were used to impregnate the samples by the full cell method. The samples were instantly placed into the 
impregnation cylinder and $0.07 \mathrm{MPa}$ vacuum was applied for $30 \mathrm{~min}$. The cylinder was then filled up with the solution and the pressure was slowly increased up to 0.6 MPa. After $2 \mathrm{~h}$, the solution was drained out of the cylinder and the final vacuum was applied at 0.05 $\mathrm{MPa}$ for $15 \mathrm{~min}$. Then, the samples were withdrawn, and their weight $\left(m_{3}\right)$ was measured. The formulation of different treatments and the concentration of materials are shown in Table 2.

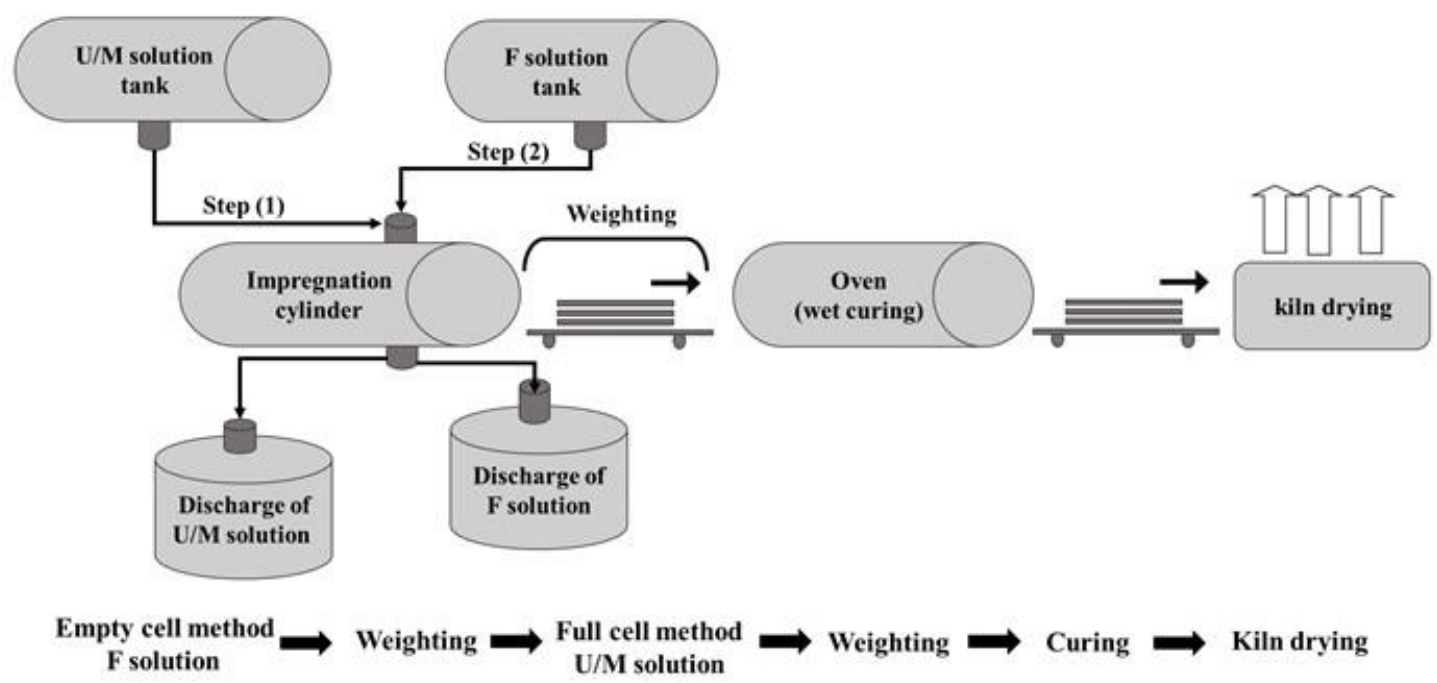

Fig. 1. The schematic representation of the $F+U / M$ treatment process

The treatment with FA was also carried out to provide a comparison. The aqueous solution of $28 \%$ FA was used to achieve the weight gain of $\approx 30 \%$. Additionally, $2 \%$ maleic anhydride (as acid catalyst) and 4\% di-sodium tetraborate (as a buffer agent) based on the total weight of the solution were added (Dong et al. 2016).

Table 2. Different Treatments Used for Impregnation of Samples (Mass/Mass Percent is Used to Express the Concentration)

\begin{tabular}{|c|c|c|}
\hline No. & Treatment & Code \\
\hline 1 & Control & $\mathrm{C}$ \\
\hline 2 & Furfural $20 \%+$ Urea 10\% / Maleic Anhydride 10\% & $\mathrm{F}_{20}+\mathrm{U}_{10} / \mathrm{M}_{10}$ \\
\hline 3 & Furfural $40 \%+$ Urea 12\%/ Maleic Anhydride 12\% & $\mathrm{F}_{40}+\mathrm{U}_{12} / \mathrm{M}_{12}$ \\
\hline 4 & Furfural $60 \%+$ Urea 12\% / Maleic Anhydride 12\% & $\mathrm{F}_{60}+\mathrm{U}_{12} / \mathrm{M}_{12}$ \\
\hline 5 & Furfural 70\% + Urea 15\% / Maleic Anhydride 15\% & $\mathrm{F}_{70}+\mathrm{U}_{15} / \mathrm{M}_{15}$ \\
\hline 6 & Furfuryl Alcohol 28\% / Maleic Anhydride 2\% / Disodium Tetra Borate 4\% & $\mathrm{FA}$ \\
\hline
\end{tabular}

Resin polymerization and drying schedule

The curing process of U/F is a complicated process and was optimized with a lot of pre-tests. First, the impregnated samples were left at room temperature for $48 \mathrm{~h}$ before being used for the curing of resin by heating. Then, they were wrapped in aluminum foil to avoid the evaporation of solution during heating. Next, the samples were placed at 50 ${ }^{\circ} \mathrm{C}$ for $12 \mathrm{~h}$. After that, the temperature was increased to $70{ }^{\circ} \mathrm{C}$ for $24 \mathrm{~h}$. Finally, the aluminum foil was removed, and the samples were placed into wood-drying kiln at $50{ }^{\circ} \mathrm{C}$ and $80 \%$ relative humidity. The temperature and the relative humidity of the kiln were changed based on a certain schedule to reach a moisture content of $10 \%$ over two weeks. 
The treated samples with FA underwent different curing process. After wrapping in aluminum foil, they were placed in an oven at $90{ }^{\circ} \mathrm{C}$ for $24 \mathrm{~h}$. The same drying schedule was used for this set of samples as the U/F samples.

The samples were further dried in the oven at $103{ }^{\circ} \mathrm{C}$ until an oven-dried state was achieved. The oven dry weight $\left(m_{4}\right)$ and the volume $\left(v_{4}\right)$ of the samples were measured after drying.

\section{Physical properties}

The WPG and bulking effect (BE) were calculated using Eqs. 1 and 2. The amounts of loaded $\mathrm{F}$ and $\mathrm{U}+\mathrm{M}$ in wood before the curing process were calculated according to Eqs. 3 and 4 and their ratio was reported as a proportion of 100 ,

$\mathrm{WPG} \%=\frac{m_{4}-m_{1}}{m_{1}} \times 100$

$\mathrm{BE} \%=\frac{V_{4}-V_{1}}{V_{1}} \times 100$

where $m_{1}, m_{4}, v_{1}$, and $v_{4}$ are the oven-dry mass of the untreated and treated samples, the oven-dry volume of untreated, and treated samples, respectively,

$$
\begin{aligned}
& F=\frac{\left(m_{2}-m_{1}\right) \times C_{\mathrm{F}}}{m_{1}} \\
& U+M=\frac{\left(m_{3}-m_{1}\right) \times C_{\mathrm{U}+M}}{m_{1}}
\end{aligned}
$$

where $m_{2}, m_{3}, C_{\mathrm{F}}$, and $C_{\mathrm{U}}+\mathrm{M}$ are the wet mass of the impregnated wood with $F$ and $U / M$, the concentration of $F$ and $U / M$ solutions, respectively.

The water absorption (WA), volumetric swelling $(S)$, anti-swelling efficiency (ASE) of samples were determined after soaking in water for immersion periods, from 2 to $336 \mathrm{~h}$. The WA\% and S\% of samples were calculated based on the increase in the sample weight $\left(m_{\mathrm{t}}\right)$ and the volume $\left(v_{\mathrm{t}}\right)$ at corresponding times following Eqs. 5 and 6 ,

$$
\begin{array}{r}
\mathrm{WA} \%=\frac{m_{\mathrm{t}}-m_{0}}{m_{0}} \times 100 \\
S \%=\frac{v_{\mathrm{t}}-v_{0}}{v_{\mathrm{o}}} \times 100 \\
\mathrm{ASE} \%=\frac{S_{\mathrm{U}}-S_{\mathrm{t}}}{S_{\mathrm{u}}} \times 100
\end{array}
$$

where $m_{0}, m_{\mathrm{t}}, v_{0}$, and $v_{\mathrm{t}}$ are the mass of the samples before and after saturation and the volumes of the samples before and after saturation, respectively. $S_{\mathrm{U}}$ and $S_{\mathrm{t}}$ are the volumetric swelling of untreated and treated sample respectively.

\section{Leaching test}

The leaching test was applied according to EN 84 (2020). This leaching test consists of dipping the wood samples in water ( 1 vol. of wood $/ 5 \mathrm{vol}$. of water), applying a vacuum of $4 \mathrm{kPa}$ for $20 \mathrm{~min}$, and changing the water after $2 \mathrm{~h}, 24 \mathrm{~h}, 48 \mathrm{~h}$, and 7 times in the remaining 12 days. The oven dry weight $\left(103^{\circ} \mathrm{C}\right)$ of samples was measured after leaching $\left(m_{5}\right)$ and the leaching rate of materials from samples was subsequently calculated by Eq. 7:

$\mathrm{LR} \%=\frac{m_{4}-m_{5}}{m_{4}} \times 100$

The chemicals converting ratio into the cured polymer (PR \%) was calculated based on $m_{5}$ by Eq. 8 (Efhamisisi et al. 2019).

$\mathrm{PR} \%=\frac{m_{5}-m_{1}}{\left(\left(m_{2}-m_{1}\right) \times C_{\mathrm{Fu}}\right)+\left(\left(m_{3}-m_{2}\right) \times C_{\mathrm{U} / \mathrm{M}}\right)} \times 100$ 


\section{Mechanical properties}

Mechanical properties were measured according to ISO 13061 series standard. The modulus of rupture (MOR), modulus of elasticity (MOE), Brinell hardness $(H)$, compression parallel to the grain $\left(C_{\mathrm{s}}\right)$ were measured by an Instron 4486 (Instru-Met Corporation, New Jersey, USA). The hardness was measured by embedding an $11.28 \mathrm{~mm}$ steel ball into wood to a half of its diameter. MOE was measured by using a constant speed of $10 \mathrm{~mm} / \mathrm{min}$; for bending strength, the speed was estimated to cause rupture in the sample. The loading speed was $10 \mathrm{~mm} / \mathrm{min}$. Impact bending strength was also performed using a pendulum impact testing machine ( 20 joules). The tests were repeated 10 times for each treatment.

\section{Accelerated Weathering Test}

Accelerated weathering tests were conducted using a Gardner weathering wheel (designed by University of Tehran, Alborz, Iran) based on the details described by Roux and Podgorski (2000). The samples were prepared based on the guidelines of modified EN 927-6 (2018) and were sanded with a sandpaper grit of 120 mesh. Then, they were fixed on the rotary wheel and underwent 90 min cycles of artificial weathering over 4 weeks. Each cycle included: $12 \mathrm{~min}$ in distilled water (bottom), $27 \mathrm{~min}$ at ambient atmosphere, 24 min under UV-340 lamps (top), and $27 \mathrm{~min}$ at ambient atmosphere. For each formulation, 5 samples were tested. After exposure to the weathering, all the samples were conditioned for 8 weeks at a temperature of $20 \pm 2{ }^{\circ} \mathrm{C}$ and a relative humidity of $60 \pm 5 \%$.

\section{Assessment of surface cracks}

The surface cracks caused by weathering were classified into three categories as follows. The number of cracks in each category was counted on the exposed surfaces and their average was reported for each treatment (Sandberg 1999).

I. Small cracks: the cracks: depth $<0.5 \mathrm{~mm}$; length $<1 \mathrm{~cm}$

II. Medium cracks: the cracks: depth 0.5 to $1 \mathrm{~mm}$; length 1 to $3 \mathrm{~cm}$

III. Large cracks: the cracks: depth $>1 \mathrm{~mm}$; length $>3 \mathrm{~cm}$

\section{Color measurement}

The CIE Lab color parameters $\left(L^{*}, a^{*}, b^{*}\right)$ were computed for each sample before and after exposure to weathering. The determination of the color coordinates was carried out by using a NRF 145 type colorimeter (3nh Global, Shiyan, China). The color parameters including $L^{*}$ (lightness), $a^{*}$ (redness), and $b^{*}$ (yellowness) were determined before and after weathering, and then the total color change $\left(\Delta E^{*}\right)$ was calculated according to Eq. 9,

$\Delta \mathrm{E}^{*}=\sqrt{\left(\Delta a^{* 2}+\Delta b^{* 2}+\Delta L^{* 2}\right)}$

where $\Delta L^{*}, \Delta a^{*}$, and $\Delta b^{*}$ are the changes of $L^{*}, a^{*}$, and $b^{*}$ color coordinates before and after the weathering test, respectively.

\section{Surface roughness}

The measurement of surface characterizations was carried out by a stylus-based profilometer. Two random locations were measured over the surface of each sample (10 repetitions for each treatment) in a direction perpendicular to the fibers using a SJ-201P roughness meter (Mitutoyo, Shimogurimachi, Japan). The roughness parameters including 
$R_{\mathrm{a}}$ (average roughness), $R_{\mathrm{Z}}$ (mean peak-to-valley height), and $R_{\mathrm{q}}$ (effective roughness) were measured before and after weathering to quantify the surface characterizations.

\section{Contact angle}

The dynamic contact angle was measured by using distilled water drops with a dosing volume of $10 \mu \mathrm{L}$. The measurements were performed before and after weathering to investigate surface wettability. Ten measurements were done for each treatment (two measurements for each sample). The samples were conditioned at standard climate (65 \pm $5 \% \mathrm{RH}$ and $22 \pm 2{ }^{\circ} \mathrm{C}$ ) before measurements were taken. The contact angle was dynamically measured over a 2 min period. The dynamic motion of water drops was captured with a high resolution video camera IXUS 185 Canon (Canon Optical products company, Tokyo, Japan) and then the obtained images were analyzed by ImageJ software (National Institutes of Health and the Laboratory for Optical and Computational Instrumentation, Madison, WI, USA) (Schneider et al. 2012).

\section{Attenuated Total Reflectance-infrared (ATR-IR) Spectroscopy}

The spectra were collected by a Bruker Tensor 27 Equinox 55 FT-IR instrument (Bruker, Billerica, MA, USA) equipped to a Universal ATR Diamond/ZnSe crystal (Bruker, Billerica, MA, USA). The IR spectra were collected directly from the thin layer of samples with a thickness of $1 \mathrm{~mm}$ in the wavenumber range of 3600 to $600 \mathrm{~cm}^{-1}$ at a spectral resolution of $4 \mathrm{~cm}^{-1}$.

\section{Statistical Analysis}

For statistical analysis, SPSS V.22 software (International Business Machines Corporation, Armonk, NY, USA) was used. One-way analysis of variance (ANOVA) analysis was used to compare the means between the treatments and the control. Finally, Duncan's multiple range test was used to group results at a 5\% significance level.

\section{RESULTS AND DISCUSSION}

\section{Physical Properties}

The color of the samples was darkened after resin curing, depending on the amount of loaded resin, and changed from brown to a spectrum of black. The surface of the samples was darker, and a lightening was observed toward their cores.

From an aesthetic point of view, the range of dark colors achieved could allow designers to substitute dark tropical timbers for this modified birch.

The WPG and density $\left(\mathrm{D}_{\mathrm{od}}\right)$ values increased by increasing the concentrations of products in the solutions (Table 3). The treatments on the wood samples increased their volume and showed the bulking effect $(\mathrm{BE})$. This could be due to the penetration of materials into the cell walls and their in-situ polymerization. As for the WPG values, BE in the samples treated with U/F resin was lower than the samples treated with FA. The maximum BE was, however, observed in $\mathrm{F}_{60}+\mathrm{U}_{12} / \mathrm{M}_{12}$. The BE in furfurylated wood ranged from $3 \%$ to $8 \%$, depending on the wood species as well as the amount of resin loaded into the wood (Dong et al. 2016).

The leaching rate (LR) of unreacted/unfixed products from the treated wood was between 2.1 and $3.9 \%$. Sejati et al. (2017) reported 3 to $4 \%$ of leachates from the modified beech wood by FA. The lower leaching rates indicate that chemicals convert more to a 
water insoluble polymer. The polymerization rate (PR\%) of materials into non-leachable polymers is also reported in Table 3 . The PR values obtained for F + U/M treatments were comparable to that found for FA-based formulation. The leaching rate of chemicals from furfurylated wood by FA is reported to be in the range of 2 to $6 \%$, which is mainly affected by wood species, WPG, acidic catalyst, and curing methods (Venås and Rinnan 2008; Dong et al. 2016; Sejati et al. 2017; Hadi et al. 2021).

Even though $\mathrm{U}$ has two reactive groups, 2 moles of $\mathrm{F}$ are required for 1 mole of $\mathrm{U}$ to form a suitable resin. With considering the molecular weight of $U$ and $F$, in a stoichiometric mixture would be $76 \mathrm{~g} \mathrm{~F}$ ( 2 moles) to $24 \mathrm{~g} \mathrm{U}$ (1 mole). The formulations containing more $\mathrm{U}$ to $\mathrm{F}$ ratio had less leaching, indicating that there was sufficient $\mathrm{U}$ for reacting with $\mathrm{F}$. The first product of the reaction between urea and furfural is monofurfurylol urea. Two monofurfurylol urea combine with forming an oxygen bridge by liberating a water molecule (Fig. 2). If there is enough furfural in the system, an extension of this polymeric network in all directions is expected by further liberation of water and the formation of oxygen bridges (Zeitsch 2000; Christiansen and Conner 1996).

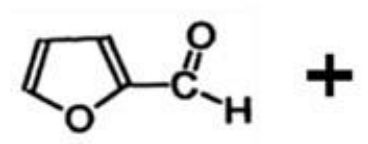

Furfural<smiles>O=CNC(O)c1ccco1</smiles>

Monofurfurylol urea<smiles>NC(N)=O</smiles>

Urea

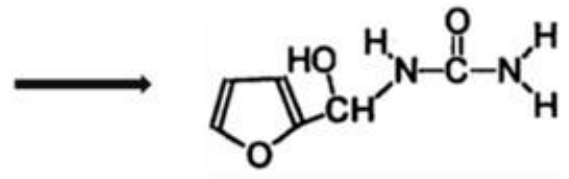

Monofurfurylol urea

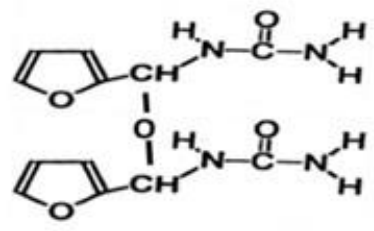

Difurfurylol urea

Fig. 2. The reaction of furfural with urea (based on Zeitsch 2000) 
Table 3. Material Proportion of Different Formulation in Wood and Related Physical Properties (Average \pm Standard Deviation)

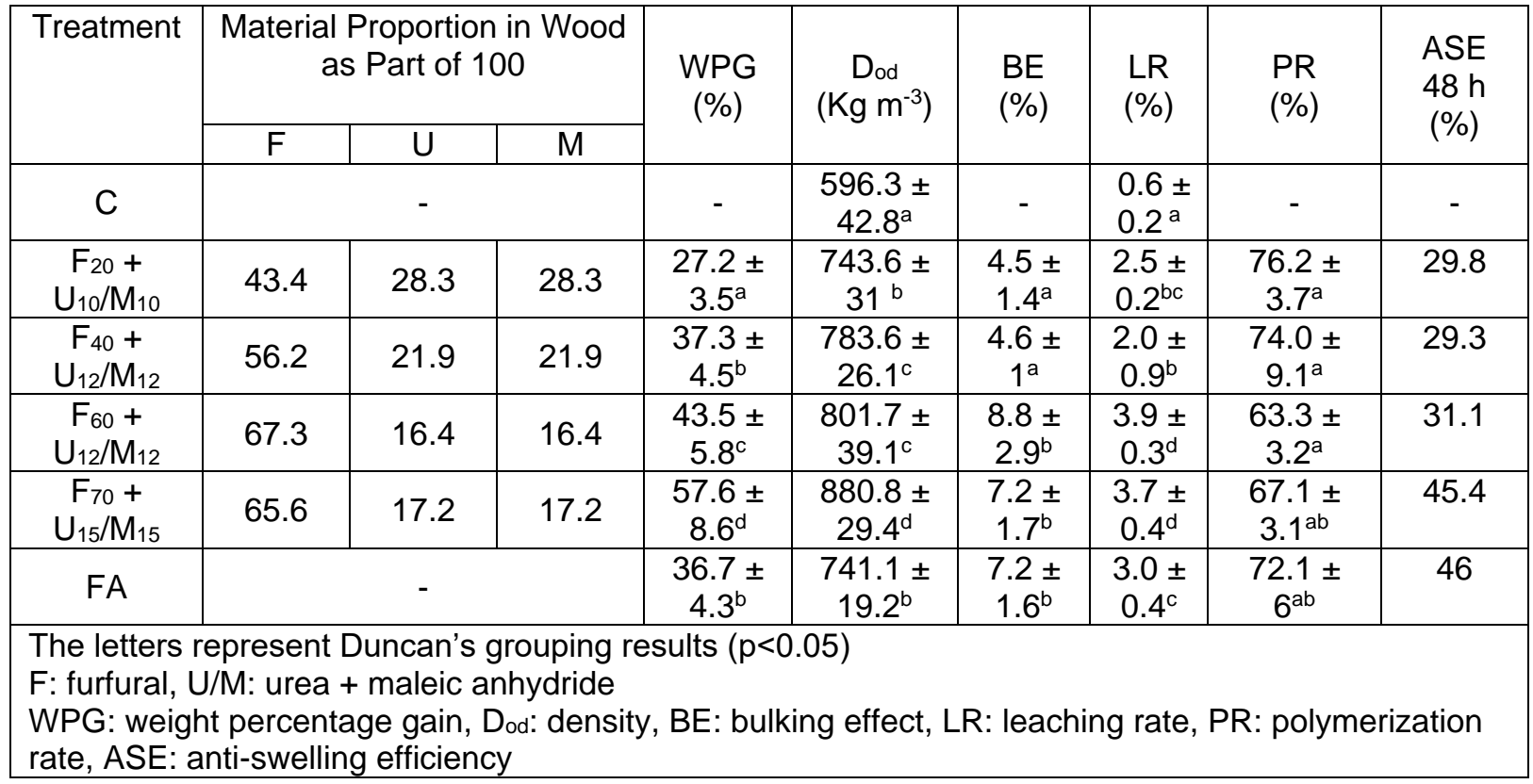

The water absorption (WA) and volumetric swelling $(S)$ of treated samples were lower than those of the control (Fig. 3). Drastic variations in the trends of WA and $S$ were observed in the first $96 \mathrm{~h}$ of soaking. After that, the fluctuations decreased, and relative stability was achieved particularly in the case of $S$. Although the lowest WA was observed in $\mathrm{F}_{70}+\mathrm{U}_{15} / \mathrm{M}_{15}$ (with maximum WPG), the lowest $\mathrm{S}$ was related to the samples modified with FA.

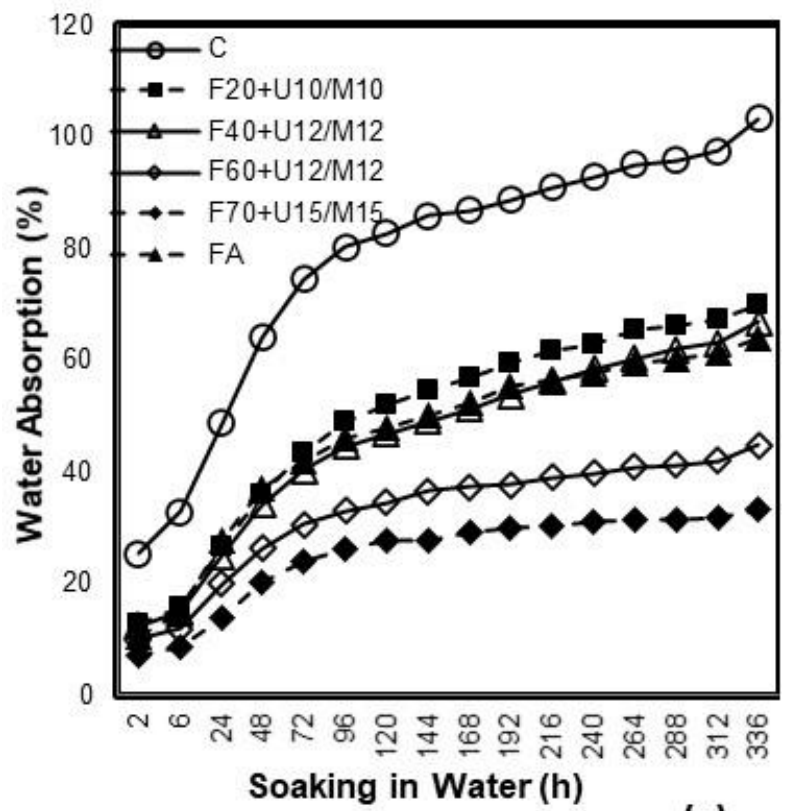

(a) 


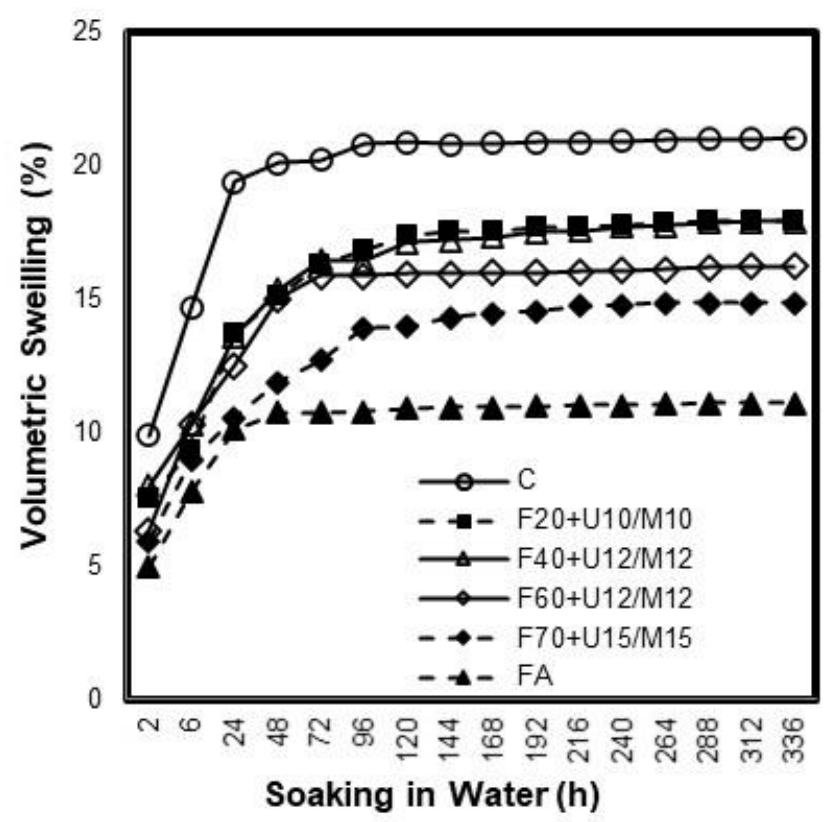

(b)

Fig. 3. Water absorption (a) and volumetric swelling (b) while soaking in water

The ASE values after $48 \mathrm{~h}$ increased by WPG increasing (29.8 to $45.4 \%$ ). The ASE values of $\mathrm{F}_{70}+\mathrm{U}_{15} / \mathrm{M}_{15}$ were similar to FA. The formation of spatial polymer networks of used material in the lumens of wood cells or even in the micropores of cell walls may explain decreases in WA and $S$ of treated wood. Shen et al. 2021 reported that the porosity and pore volume of furfurylated woods decreased with raising WPG. On the other hand, the possibility of sporadically covalent bonds of $\mathrm{F}+\mathrm{U} / \mathrm{M}$ resin with the polymers of cell walls should not be overlooked. The random reacting of FA resin with the wood components in particular lignin has already been documented (Thygesen et al. 2010; Li et al. 2015). The presence of un-leachable polymers inside the wood and its cross-linking with the lignin-polysaccharide matrix of cell walls influence several properties of the treated wood (Hill 2006; Reinprecht 2016).

\section{Mechanical Properties}

Some mechanical properties including compression strength $(C \mathrm{~s})$, modulus of rupture (MOR), and modulus of elasticity (MOE) were increased, as the values of WPG increased (Table 4). The above-mentioned properties for FA also increased compared to the average of the control samples. The formation of hard polyFA resin into the wood and its co-effect on the hygroscopicity are the main reasons for the higher mechanical strength of furfurylated wood. This is affected by the amount and the type of catalysts, curing temperature, concentration of FA in treating solution, etc. (Epmeier et al. 2004; Li et al. 2017; Sejati et al. 2017).

The treatment of wood with $\mathrm{F}+\mathrm{U} / \mathrm{M}$ resins decreased the hardness and the impact bending strength. However, this was not statistically significant because of considerable difference between the samples of the same formulation. The strong acidic reaction condition that was used for resin curing may explain decrease in hardness and impact bending of treated wood with furan-based resins. Another reason can be rooted in the methods used for resin curing as well as choosing the right temperature, humidity, and 
drying schedule. The proper procedure for the curing of resin and the drying of treated wood could help to reduce the collapse of wood cell walls.

The hardness of the treated samples with FA increased slightly compared to the control samples. However, their resistance to impact bending was less than that of the control and even of the $\mathrm{F}+\mathrm{U} / \mathrm{M}$ resin treated samples. It has been reported that the tension perpendicular to the grain as well as impact bending are adversely affected by FA treatment (Lande et al. 2004; Abdolzadeh et al. 2014). The main reason is that the polymer matrix is very rigid and thus increases the brittleness. The irreversible bulking in cell walls as well as development of microscopic cracks have been mentioned as reasons for this (Efhamisisi et al. 2019).

Table 4. Mechanical Properties of Wood Sample (Average \pm Standard Deviation)

\begin{tabular}{|c|c|c|c|c|c|}
\hline Treatment & CS (MPa) & MOR (MPa) & MOE $(\mathrm{MPa})$ & $\mathrm{H}(\mathrm{kN})$ & IB $(\mathrm{kg} . \mathrm{m})$ \\
\hline $\mathrm{C}$ & $79.6 \pm 11.9^{\mathrm{a}}$ & $147.6 \pm 16.6^{\mathrm{a}}$ & $15556 \pm 1982^{\mathrm{a}}$ & $3.5 \pm 0.3$ & $4.3 \pm 0.8$ \\
\hline $\mathrm{F}_{20}+\mathrm{U}_{10} / \mathrm{M}_{10}$ & $102.08 \pm 15.05^{\mathrm{b}}$ & $169.2 \pm 5^{\mathrm{bc}}$ & $18258.3 \pm 2215^{\mathrm{bc}}$ & $3.2 \pm 0.3$ & $3.61 \pm 0.4$ \\
\hline $\mathrm{F}_{40}+\mathrm{U}_{12} / \mathrm{M}_{12}$ & $100.4 \pm 15.8^{\mathrm{b}}$ & $176.5 \pm 20.2^{\mathrm{bc}}$ & $18018 \pm 2223.9^{\mathrm{b}}$ & $3.3 \pm 0.3$ & $3.4 \pm 0.4$ \\
\hline $\mathrm{F}_{60}+\mathrm{U}_{12} / \mathrm{M}_{12}$ & $103.2 \pm 11.2^{\mathrm{b}}$ & $174.2 \pm 12.9^{\mathrm{bc}}$ & $18430 \pm 1777.5^{\mathrm{bc}}$ & $3.3 \pm 0.5$ & $3.5 \pm 0.6$ \\
\hline $\mathrm{F}_{70}+\mathrm{U}_{15} / \mathrm{M}_{15}$ & $105.4 \pm 11.3^{\mathrm{b}}$ & $187.8 \pm 17.05^{\mathrm{c}}$ & $20678.3 \pm 869.6^{\mathrm{c}}$ & $3.2 \pm 0.5$ & $3.7 \pm 0.3$ \\
\hline \multicolumn{7}{|c|}{$\mathrm{FA}$} & $119.7 \pm 5.4^{\mathrm{c}}$ & $167.6 \pm 13.9^{\mathrm{b}}$ & $18238.5 \pm 2450^{\mathrm{bc}}$ & $3.6 \pm 0.5$ & $3.4 \pm 0.6$ \\
\hline The letters represent Duncan's grouping results $(\mathrm{p}<0.05)$ \\
Cs: compression strength, MOR: modulus of rupture, MOE: modulus of elasticity, H: hardness, \\
IB: impact bending strength
\end{tabular}

\section{Accelerated Weathering}

\section{Visual observation}

The exposed surfaces of the samples before and after weathering are shown in Fig. 4. The treated samples had a deep brown to dark brown color that was changed to a silvergray after weathering.

The examination of the number of cracks at the exposed surface showed that the treated samples had fewer small cracks but more medium and deep ones compared to the controls (Table 5). The deeper cracks in the treated wood may be due to the consequences of wood collapse. This often happens with resin modification and can be attributed to the rigid resin matrix which causes additional tensions during swelling and shrinking. This problem can be solved by optimizing the acidity of the impregnation solutions as well as the approach used for resin curing or drying of the treated samples.

Table 5. Number of Cracks Observed in Exposed Surfaces to Accelerated Weathering

\begin{tabular}{|c|c|c|c|}
\hline Treatment & $\begin{array}{l}\text { Small Cracks } \\
\text { Per Each Square Inch }\end{array}$ & $\begin{array}{l}\text { Medium Cracks } \\
\text { Per All the Surface }\end{array}$ & $\begin{array}{c}\text { Deep Cracks } \\
\text { Per All the Surface }\end{array}$ \\
\hline $\mathrm{C}$ & 18.3 & 2.3 & 1 \\
\hline $\mathrm{F}_{20}+\mathrm{U}_{10} / \mathrm{M}_{10}$ & 8.1 & 2.3 & 1 \\
\hline $\mathrm{F}_{40}+\mathrm{U}_{12} / \mathrm{M}_{12}$ & 9.4 & 4.5 & 3 \\
\hline $\mathrm{F}_{60}+\mathrm{U}_{12} / \mathrm{M}_{12}$ & 8.4 & 3 & 2.7 \\
\hline $\mathrm{F}_{70}+\mathrm{U}_{15} / \mathrm{M}_{15}$ & 10.7 & 6.3 & 4.7 \\
\hline $\mathrm{FA}$ & 8.2 & 1 & 5 \\
\hline
\end{tabular}




\section{Color changes}

The difference of each color parameters $\left(L^{*}, a^{*}, b^{*}\right)$ and the total color difference $\left(\Delta E^{*}\right)$ before and after weathering are summarized in Table 6 . The value of $\Delta L^{*}$ for controls was negative, which means they became darker after weathering. The values of $\Delta L^{*}$ were positive for treated wood. The highest mean value of $\Delta L^{*}$ was determined for $\mathrm{F}_{20}+\mathrm{U}_{10} / \mathrm{M}_{10}$, which clearly confirms the lightening of the surface after weathering. It was reported that furfurylated wood by FA shows positive $\Delta L^{*}$ values, indicating that the wood surface becomes lighter (Temiz et al. 2007).

Table 6. Color Change of the Treated and Untreated Birch Wood Due to Weathering (Average \pm Standard Deviation)

\begin{tabular}{|c|c|c|c|c|}
\hline Treatment & $\Delta L^{*}$ & $\Delta a^{*}$ & $\Delta b^{*}$ & $\Delta E^{*}$ \\
\hline C & $-4.5 \pm 1.8^{a}$ & $-4.7 \pm 0.4^{b}$ & $-1.9 \pm 0.7^{a}$ & $5.2 \pm 0.7^{a}$ \\
\hline $\mathrm{F}_{20}+\mathrm{U}_{10} / \mathrm{M}_{10}$ & $30.2 \pm 3.3^{b}$ & $-1.1 \pm 0.5^{b}$ & $6.02 \pm 2.22^{b}$ & $30.7 \pm 3.7^{c}$ \\
\hline$F_{40}+U_{12} / M_{12}$ & $5.2 \pm 2.7^{c}$ & $-2.9 \pm 0.2^{a}$ & $6.66 \pm 2.37^{b}$ & $10.3 \pm 2.01^{b}$ \\
\hline $\mathrm{F}_{60}+\mathrm{U}_{12} / \mathrm{M}_{12}$ & $6.8 \pm 1.5^{c}$ & $-1.4 \pm 0.6^{b}$ & $4.3 \pm 0.93^{b c}$ & $8.1 \pm 2.3^{b}$ \\
\hline $\mathrm{F}_{70}+\mathrm{U}_{15} / \mathrm{M}_{15}$ & $5.6 \pm 2.8^{c}$ & $1.9 \pm 0.4^{c}$ & $3.48 \pm 1.2^{\mathrm{bc}}$ & $6.8 \pm 0.9^{c}$ \\
\hline FA & $9.7 \pm 4.4^{c}$ & $-1.1 \pm 0.4^{b}$ & $2.32 \pm 1.24^{\mathrm{c}}$ & $10.6 \pm 4.5^{\mathrm{b}}$ \\
\hline
\end{tabular}

The values of $\Delta a^{*}$ were negative in all treatments except for $\mathrm{F}_{70}+\mathrm{U}_{15} / \mathrm{M}_{15}$. The $a^{*}$ axis represents the green-red component, with green in the negative direction and red in the positive direction. This means that the treated samples with negative $\Delta a^{*}$ had a greenish appearance a spectrum after weathering. The minimum $\Delta b^{*}$ was observed for the control samples, which means they were inclined to the blue spectrum after weathering. The $b^{*}$ axis represents the blue-yellow component, with blue in the negative direction and yellow in the positive direction. The treated samples showed higher total color difference $\left(\Delta E^{*}\right)$ than the control. The highest mean value of $\Delta E^{*}$ was observed in $\mathrm{F}_{20}+\mathrm{U}_{10} / \mathrm{M}_{10}$, which showed a systematic trend to the lower values with increasing WPG. The color changes of FA treated samples were more or less similar to that of the $\mathrm{F}+\mathrm{U} / \mathrm{M}$ treated ones with higher WPG. Mantanis and Lykidis (2015) studied the natural weathering performance of furfurylated deck wood after 3 years and reported that the decks exhibited extensive greying effects on their surfaces.

Wood surface ro

Wood surface roughness

The values of roughness parameters before and after weathering are shown in Table 7. Before weathering, the surface of treated samples showed higher values of roughness parameters compared to the control. It was earlier reported that furfurylated wood of beech and fir had a rougher surface than the control (Talaei et al. 2016). 


\section{bioresources.com}

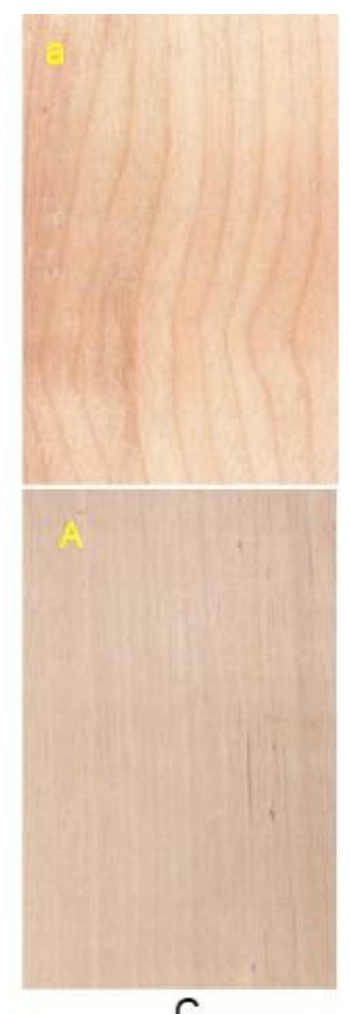

C
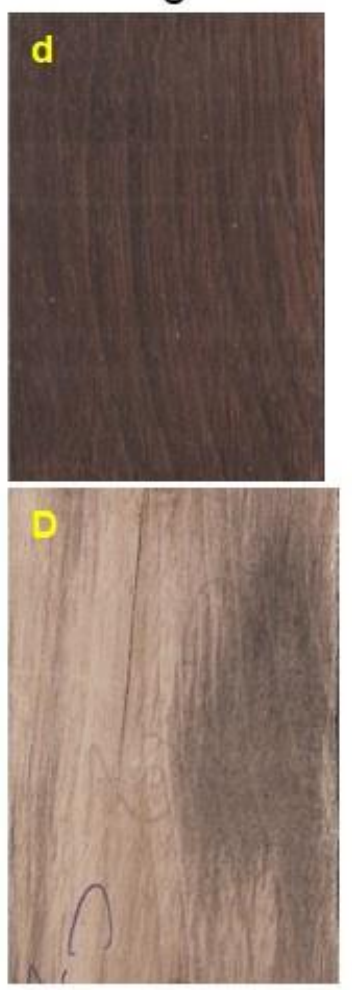

$F_{60}+U_{12} / M_{12}$

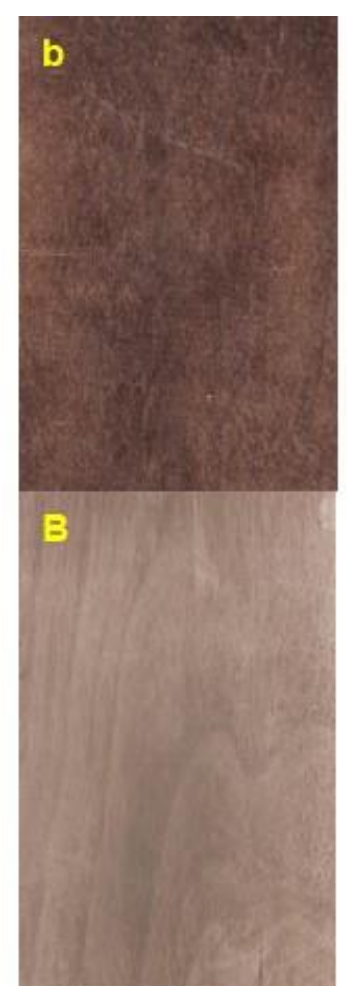

$F_{20}+U_{10} / M_{10}$

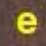

e
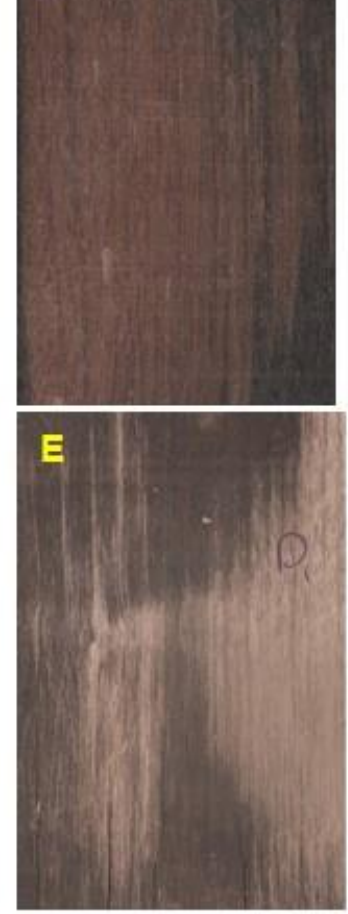

$F_{70}+U_{15} / M_{15}$

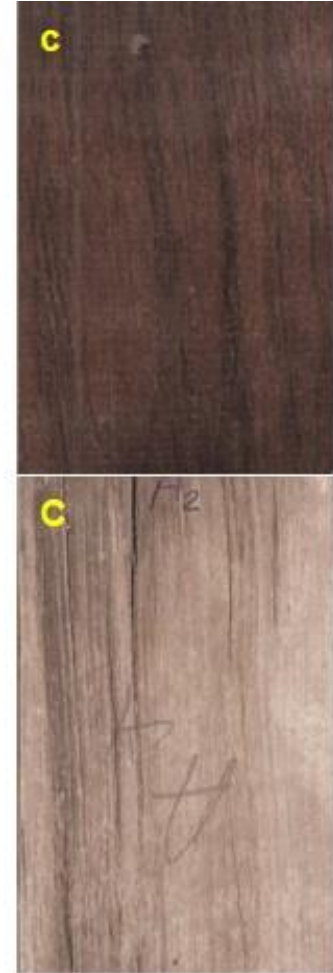

$$
F_{40}+U_{12} / M_{12}
$$

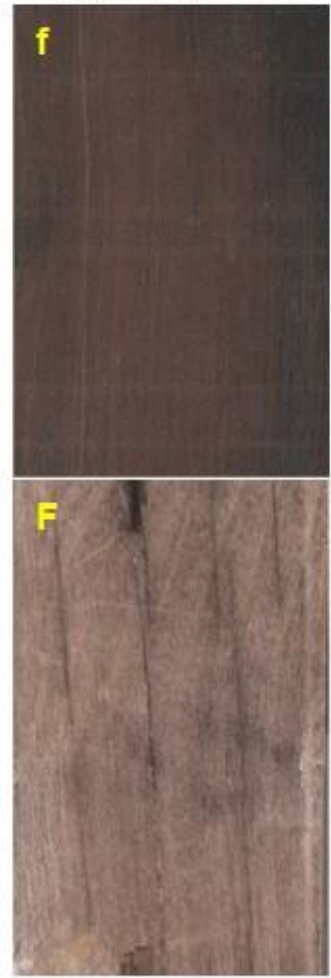

FA

Fig. 4. The surface of control and treated samples before (a, b, c, d, e, and f) and after accelerated weathering $(A, B, C, D, E$, and $F)$ 
This phenomenon can be partly explained by the fact that the acidic conditions were used during the impregnation process. The roughness of the wood surface increases when in contact with acidic solutions (Reinprecht 2016). In contrast, the introduction of resin into the cell walls causes a bulking effect that can subsequently create higher porosity (Talaei et al. 2016). Among the treated samples, the lowest values of roughness parameters were observed in $\mathrm{F}_{70}+\mathrm{U}_{15} / \mathrm{M}_{15}$ (Maximum WPG). Through increasing WPG, it seems that a higher amount of resin remained in the cell lumens. This can also have a decreasing effect on the roughness parameters. Li et al (2016) reported that in the wood furfurylation by FA, with lower concentration solutions more resins were penetrated in the cell walls than cell lumens.

The average values of roughness parameters were increased after weathering. However, the treated samples showed much less variation compared to the controls. In fact, although the control samples had less roughness before weathering, they were more strongly roughened after exposure to weathering.

Table 7. Roughness Parameters of Surface ( $R_{\mathrm{a}}, R_{\mathrm{z}}$, and $\left.R_{\mathrm{q}}\right)$ Before and After Weathering (Average \pm Standard Deviation)

\begin{tabular}{|c|c|c|c|c|c|c|c|c|c|}
\hline \multirow{2}{*}{ Treat. } & \multicolumn{2}{|c|}{$\begin{array}{c}R_{\mathrm{a}} \\
(\mu \mathrm{m})\end{array}$} & \multirow{2}{*}{$\begin{array}{l}\text { Var. } \\
\text { of } R_{\mathrm{a}} \\
(\%)\end{array}$} & \multicolumn{2}{|c|}{$\begin{array}{c}R_{z} \\
(\mu \mathrm{m})\end{array}$} & \multirow{2}{*}{$\begin{array}{c}\text { Var. } \\
\text { of } \\
R_{\mathrm{z}} \\
(\%)\end{array}$} & \multicolumn{2}{|c|}{$\begin{array}{c}R_{\mathrm{q}} \\
(\mu \mathrm{m})\end{array}$} & \multirow{2}{*}{$\begin{array}{c}\text { Var. } \\
\text { of } \\
R_{\mathrm{q}} \\
(\%)\end{array}$} \\
\hline & Unweathered & Weathered & & Unweathered & Weathered & & Unweathered & Weathered & \\
\hline C & $4.3 \pm 1.8$ & $10.9 \pm 1.1$ & 151.8 & $46.8 \pm 2.5$ & $72.4 \pm 3.2$ & 54.8 & $6.6 \pm 2.2$ & $12.7 \pm 1.5$ & 92.7 \\
\hline $\begin{array}{c}F_{20}+ \\
U_{10} / M_{10}\end{array}$ & $9.0 \pm 2.2$ & $12.0 \pm 1.7$ & 33.3 & $78.7 \pm 5.2$ & $92 \pm 7.6$ & 16.9 & $12.7 \pm 1.9$ & $16.5 \pm 1.9$ & 30.2 \\
\hline $\begin{array}{c}F_{40+} \\
U_{12} / M_{12}\end{array}$ & $7.1 \pm 0.8$ & $11.0 \pm 0.4$ & 55.6 & $61.4 \pm 3.3$ & $90.2 \pm 4$ & 46.8 & $10.8 \pm 0.7$ & $15.4 \pm 0.4$ & 42.1 \\
\hline $\begin{array}{c}\mathrm{F}_{60+} \\
\mathrm{U}_{12} / \mathrm{M}_{12}\end{array}$ & $9.2 \pm 2.0$ & $11.6 \pm 1.8$ & 25.7 & $78.7 \pm 5.7$ & $94.6 \pm 8.1$ & 20.2 & $13.6 \pm 1.6$ & $16.7 \pm 1.6$ & 22.7 \\
\hline $\begin{array}{c}\mathrm{F}_{70+} \\
\mathrm{U}_{15} / \mathrm{M}_{15}\end{array}$ & $6.2 \pm 0.5$ & $9.0 \pm 0.8$ & 44.4 & $66.5 \pm 1.9$ & $83 \pm 2$ & 24.8 & $9.3 \pm 1$ & $12.7 \pm 0.6$ & 35.9 \\
\hline FA & $7.3 \pm 1.3$ & $8.8 \pm 1.2$ & 21.5 & $63.5 \pm 5.3$ & $78.4 \pm 6.5$ & 23.4 & $11.2 \pm 1.2$ & $13.4 \pm 1.6$ & 19.9 \\
\hline
\end{tabular}

\section{Dynamic Contact angle of water}

The treated samples showed much higher contact angle of water drop compared to the controls especially at longer times after dropping (Fig. 5a). The contact angle decreased more rapidly during the initial $15 \mathrm{~s}$. The maximum contact angle of water drop after $120 \mathrm{~s}$ of exposure was obtained for $\mathrm{F}_{40}+\mathrm{U}_{12} / \mathrm{M}_{12}$. Dong et al. (2015) reported that a higher WPG of polyFA in the wood causes higher hydrophobicity and lower dynamic wettability (higher contact angle). However, in the current study the maximum WPG did not result in the highest contact angle. This may be because of the formation of microscopic cracks in the cell walls due to the high acidity of the impregnation solutions with the higher concentration of $\mathrm{F}$.

After the weathering, a significant decrease of contact angle was observed for all the samples (Fig. 5b). The contact angle of the treated samples with FA was surprisingly lower than that of the controls at the end of the test. However, the samples treated with $\mathrm{F}_{40}$ $+\mathrm{U}_{12} / \mathrm{M}_{12}$ still had the highest contact angle. 


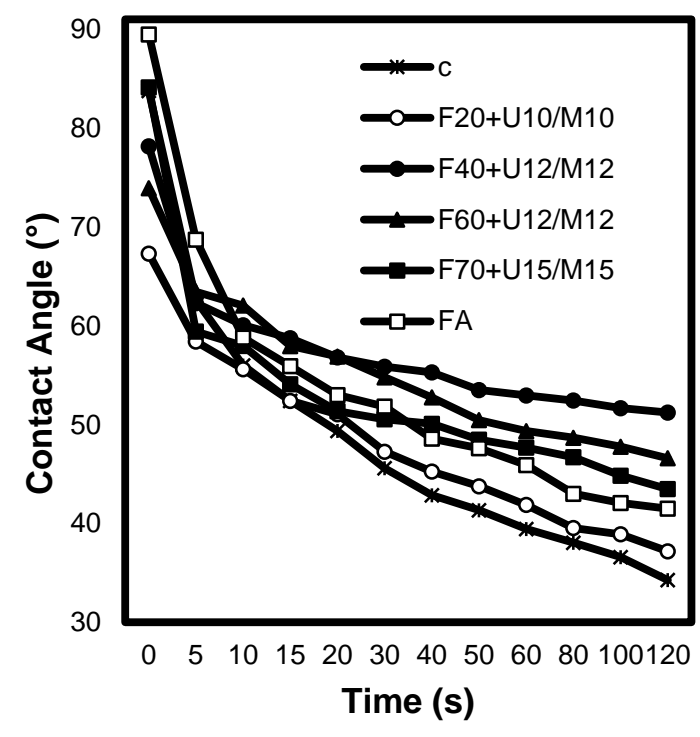

(a)

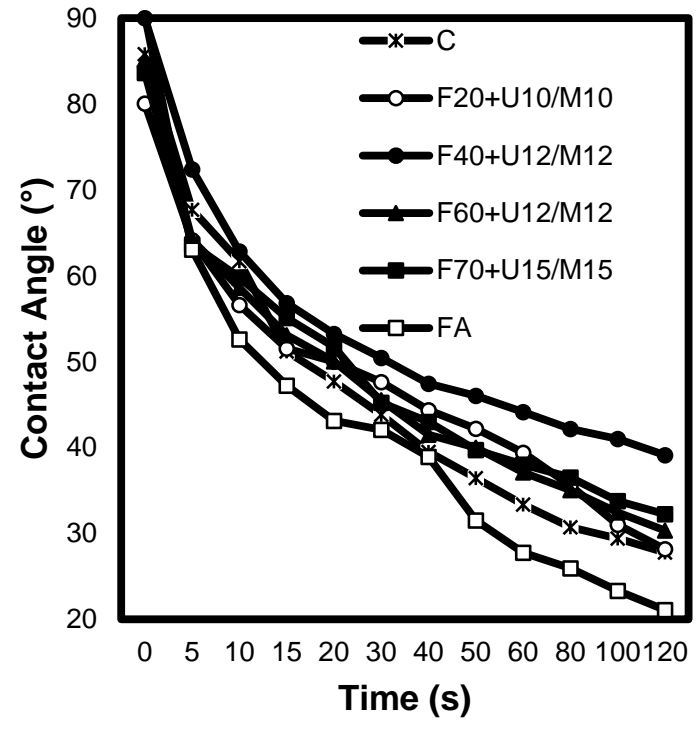

(b)

Fig. 5. Contact angle as a function of time for wood sample before weathering (a), and after weathering (b)

\section{ATR-FTIR Spectroscopy}

Figure 6 shows the ATR-FTIR spectra of untreated sample as well as wood treated with $\mathrm{FA}$ and $\mathrm{F}+\mathrm{U} / \mathrm{M}$ resins over the range of 600 to $3600 \mathrm{~cm}^{-1}$. Some differences in transmittance peaks (i.e., increase and/or decrease) were observed as a result of the treatments on wood samples. Generally, there was not complete disappearance of already existing peaks and neither appearance of new peaks.

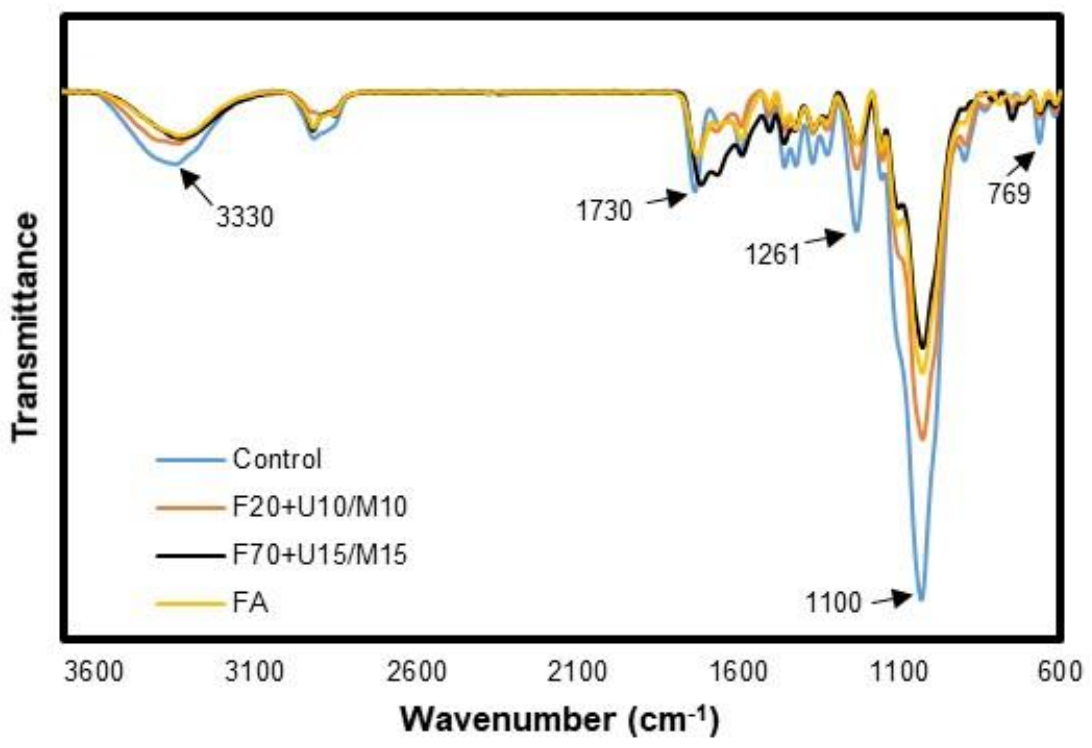

Fig. 6. ATR-FTIR spectra for treated and untreated birch wood between 3600 to $600 \mathrm{~cm}^{-1}$

The prominent and broad band at around $3330 \mathrm{~cm}^{-1}$ is assigned to the stretching of -OH groups (Gupta et al. 2015). The changes in the spectra around this wavenumber might also be due to various moisture levels in the samples (Jelle et al. 2012). The intensity of 
the mentioned peak in the treated samples was lower than the untreated control, which confirms less water absorption from the environment during the test. The peaks around 3000 to $2800 \mathrm{~cm}^{-1}$ were probably due to $-\mathrm{C}-\mathrm{H}$ - stretching vibration assigned to methyl $\left(\mathrm{CH}_{2}\right)$ and methylene $\left(\mathrm{CH}_{3}\right)$ groups. The peak around 1730 to $1710 \mathrm{~cm}^{-1}$ is attributed to the $\mathrm{C}=\mathrm{O}$ (carbonyl) stretching in hemicellulose and urea (Lionetto et al. 2012). The peak around $1510 \mathrm{~cm}^{-1}$ rises from the $\mathrm{C}=\mathrm{C}$ stretching of the aromatic ring in lignin (Jelle et al. 2012). These two peaks are good criteria to study the effect of weathering on the wood decomposition.

The stretching transmittance observed at 1648 to $1670 \mathrm{~cm}^{-1}$ particularly for $\mathrm{F}_{70}+$ $\mathrm{U}_{15} / \mathrm{M}_{15}$ is related to the amide group in the structure of urea furfural resin (Khandarkar $e t$ al. 2014). The peak around $1048 \mathrm{~cm}^{-1}$ is attributed to the $\mathrm{C}$ vibration of cellulose and hemicellulose (Ganne-Chédeville et al. 2012). The peak at $796 \mathrm{~cm}^{-1}$ is assigned to skeletal vibration of 2,5-disubstituted furan rings (Dong et al. 2015) that shifted to $769 \mathrm{~cm}^{-1}$ for FA and $750 \mathrm{~cm}^{-1}$ for $\mathrm{F}+\mathrm{U} / \mathrm{M}$ resin.
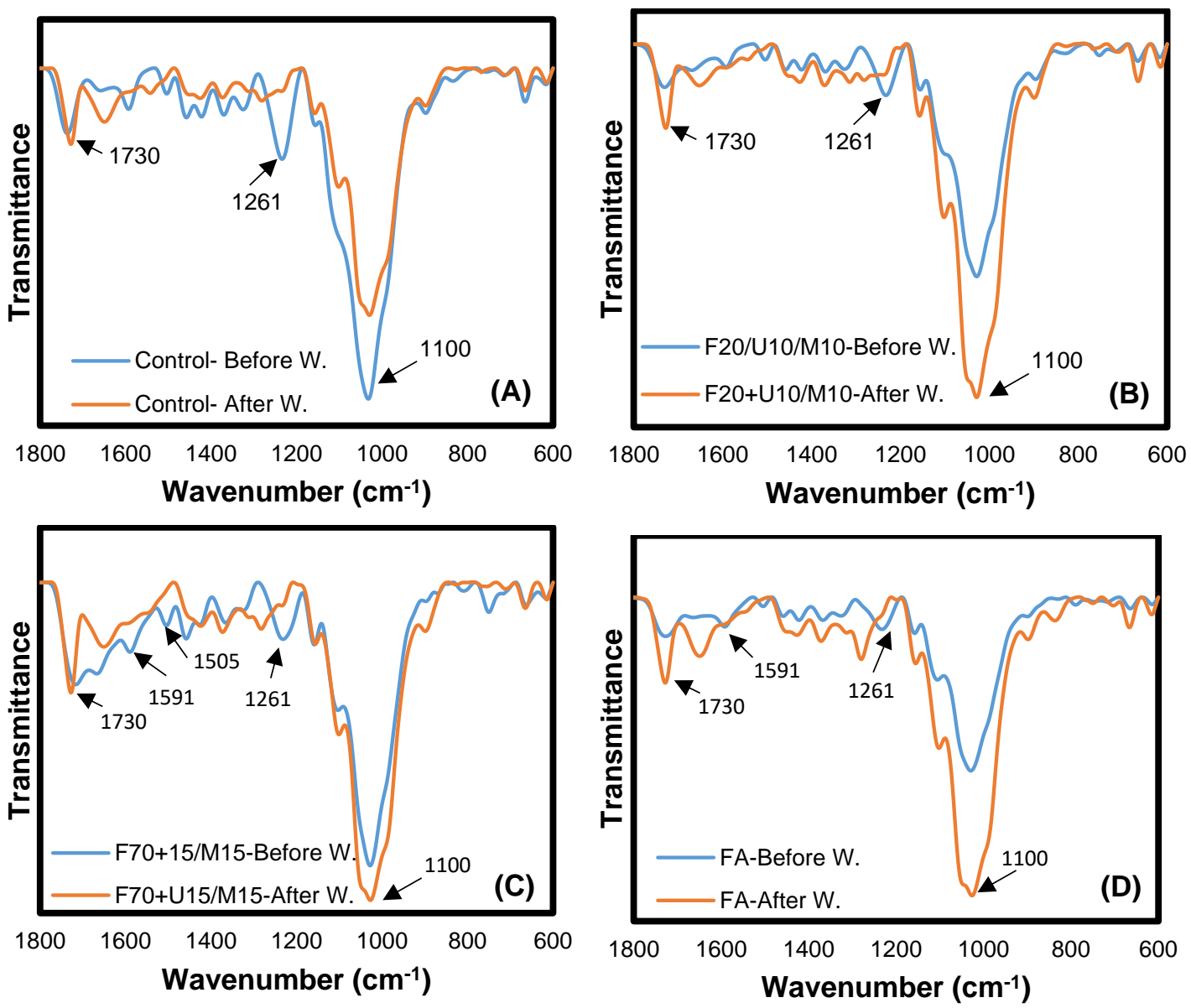

Fig. 7. ATR-FTIR spectra for before and after the accelerated weathering: (A) control birch wood, (B) $\mathrm{F}_{20}+\mathrm{U}_{10} / \mathrm{M}_{10},(\mathrm{C}) \mathrm{F}_{70}+\mathrm{U}_{15} / \mathrm{M}_{15}$, and (D) $\mathrm{FA}$

The changes in ATR-FTIR spectra before and after the accelerated weathering for treated and untreated samples are shown in Fig. 7. After weathering, the intensity of the peak at around $1730 \mathrm{~cm}^{-1}$ was increased in all samples. Lignin is the most sensitive component to photodegradation, and the intensities of its characteristic bands decreased significantly during the process of weathering (Mirshokraie et al. 2014). This is often 
accompanied by the formation of a new chromophore non-conjugated carbonyl group appearing at around $1730 \mathrm{~cm}^{-1}$. It should be noted, however, that this wavenumber also applies to carbonyl stretching in hemicellulose, which can be decreased due to the degradation of acetyl groups. The characteristic bands of lignin structures at around 1592 and $1505 \mathrm{~cm}^{-1}$ disappeared during exposure to the accelerated weathering. Pandey (2005) reported that a 1506 to $1511 \mathrm{~cm}^{-1}$ peak (related to the aromatic $\mathrm{C}=\mathrm{C}$ structure in lignin) disappears within a few hours of exposure.

The peak at around $1261 \mathrm{~cm}^{-1}$ for CO stretching in lignin also disappeared after weathering. The intensity of the peak at around $1100 \mathrm{~cm}^{-1}$, which is perhaps assigned to cellulose for hydroxyl bending (Lionetto et al. 2012), was decreased in the control and increased in the treated samples. The ATR-FTIR spectroscopy showed that the furan resins had little effect on the protection of lignin from weathering. Therefore, shortly after weathering the color of the furfurylated wood changed to silver-gray.

\section{CONCLUSIONS}

1. The authors' preliminary studies showed that the furfural $(\mathrm{F})+$ urea/maleic anhydride (U/M) resin compared to the industrial formulation based on the furfuryl alcohol (FA) suggests a new approach for modification of wood properties.

2. The physical properties showed that as the concentrations of products in the solutions increased, weight percent gain (WPG) and density of treated wood were increased. The maximum bulking effect $(\mathrm{BE})$ was observed in $\mathrm{F}_{60}+\mathrm{U}_{12} / \mathrm{M}_{12}$. The leaching rate of the polymer was 2 to $4 \%$. The WA and S were decreased by increased WPG.

3. The mechanical properties showed that some of the mechanical properties including $\mathrm{CP}, \mathrm{MOR}$, and MOE increased as the values of WPG increased (maximum $\mathrm{F}_{70}+$ $\left.\mathrm{U}_{15} / \mathrm{M}_{15}\right)$. The treatment of wood with $\mathrm{F}+\mathrm{U} / \mathrm{M}$ resins decreased the hardness and the impact bending.

4. The accelerated weathering showed that UV absorption of the treated wood was higher than the control because of its dark color. However, the color change of treated wood decreased as the values of WPG increased. The roughness change of treated wood was lower than the control. The maximum contact angle before and after weathering was observed in $\mathrm{F}_{40}+\mathrm{U}_{12} / \mathrm{M}_{12}$. The ATR-FTIR spectroscopy showed that the furan resins have little effect on the protection of lignin against accelerated weathering.

5. The high acidity of furfural-based solutions is one of the issues requiring additional studies. If the alkaline $\mathrm{pH}$ is used, the curing of the resin will be disturbed and the leaching rate will increase, whereas acidic $\mathrm{pH}$ also has a destructive effect on the wood texture. This approach still needs further study for commercialization and industrial recommendation. 


\section{ACKNOWLEDGMENTS}

This work was supported by the Center for International Scientific Studies \& Collaboration (CISSC, Tehran, Iran) and Campus France (Paris, France) through the Gundishapur project no. $40916 \mathrm{NJ}$.

\section{REFERENCES CITED}

Abdolzadeh, H., Ebrahimi, G., Layeghi, M., Ghasemieh, M., and Mirshokrai, A. (2013). "Mechanical properties of beech-furfuryl alcohol wood polymer," Iranian Journal of Wood and Paper Industries 4(2), 131-140. (In Persian)

Abdolzadeh, H., Ebrahimi, G., Layeghi, M., Ghassemieh, M., and Mirshokraei, A. (2014). "Fracture behavior of beech-furan wood/polymer under mode I," Iranian Journal of Wood and Paper Science Research 29(4), 609-618. DOI:

10.22092/ijwpr.2014.8456 (In Persian)

Ahmadi, H., Hamassi, H., and Mahdavi, S. (2015). "Investigation on mechanical properties of composite from recycled HDPE filled by furfural residue produced from bagasse," Iranian Journal of Wood and Paper Science Research 30(3), 376-387. DOI: 10.22092/ijwpr.2015.13004 (In Persian)

Buchelt, B., Dietrich, T., and Wagenführ, A. (2012). "Macroscopic and microscopic monitoring of swelling of beech wood after impregnation with furfuryl alcohol," European Journal of Wood and Wood Products 70(6), 865-869. DOI: 10.1007/s00107-012-0631-x

Christiansen, A. W., and Conner, A. H. (1996). Wood Adhesives 1995, U.S. Department of Agriculture, Forest Service, Forest Products Laboratory, Portland, OR, USA, 1996.

Dong, Y., Qin, Y., Wang, K., Yan, Y., Zhang, S., Li, J., and Zhang, S. (2016). "Assessment of the performance of furfurylated wood and acetylated wood: Comparison among four fast-growing wood species," BioResources 11(2), 36793690. DOI: 10.15376/biores.11.2.3679-3690

Dong Y., Yan Y., Zhang S., and Li J. (2014). "Wood/polymer nanocomposites prepared by impregnation with furfuryl alcohol and Nano-SiO2," BioResources 9(4), 60286040. DOI: 10.15376/biores.9.4.6028-6040

Dong, Y., Yan, Y., Zhang, S., Li, J., and Wang, J. (2015). "Flammability and physicalmechanical properties assessment of wood treated with furfuryl alcohol and nano$\mathrm{SiO}_{2}$," European Journal of Wood and Wood Products 73(4), 457-464. DOI: 10.1007/s00107-015-0896-y

Efhamisisi, D., Sharifat, M., Thevenon, M. F., Tarmian, A., and Jonoobi, M. (2019). "Evaluation of furfural/urea complexes to improve physico-mechanical properties of birch wood," Journal Wood and Forest Science and Technology 25(4), 117-134. DOI: 10.22069/JWFST.2018.15280.1758 (In Persian)

EN 84 (2020). "Durability of wood and wood-based products - Accelerated ageing of treated wood prior to biological testing - Leaching procedure," European Committee for Standardization, Brussels, Belgium.

EN 927-6 (2018). "Paints and varnishes - Coating materials and coating systems for exterior wood - Part 6: Exposure of wood coatings to artificial weathering using fluorescent UV lamps and water," European Committee for Standardization, Brussels, Belgium. 
Epmeier, H., Westin, M., and Rapp, A. (2004). "Differently modified wood comparison of some selected properties," Scandinavian Journal of Forest Research 19(5), 31-37. DOI: $10.1080 / 02827580410017825$

Esteves, B., Nunes, L., and Pereira, H. (2011). "Properties of furfurylated wood (Pinus pinaster)," European Journal of Wood and Wood Products 69(4), 521-525. DOI: 10.1007/s00107-010-0480-4

Ganne-Chédeville, C., Jääskeläinen, A., Froidevaux, J., Hughes, M., and Navi, P. (2012). "Natural and artificial ageing of spruce wood as observed by FTIR-ATR and UVRR spectroscopy," Holzforschung 66(2), 163-170. DOI: 10.1515/HF.2011.148

Gérardin, P. (2016). "New alternatives for wood preservation based on thermal and chemical modification of wood - A review," Annals of Forest Science 73(3), 559570. DOI: $10.1007 / \mathrm{s} 13595-015-0531-4$

Ghafari, R., DoostHosseini, K., Abdulkhani, A., and Mirshokraie, S. A. (2016). "Replacing formaldehyde by furfural in urea formaldehyde resin: Effect on formaldehyde emission and physical-mechanical properties of particleboards," European Journal of Wood and Wood Products 74(4), 609-616. DOI: $10.1007 / \mathrm{s} 00107-016-1005-6$

Gindl, W., Zargar-Yaghubi, F., and Wimmer, R. (2003). "Impregnation of softwood cell walls with melamine-formaldehyde resin," Bioresource Technology 87(3), 325-330. DOI: $10.1016 / \mathrm{S} 0960-8524(02) 00233-\mathrm{X}$

Gupta, B. S., Jelle, B. P., and Gao, T. (2015). "Wood facade materials ageing analysis by FTIR spectroscopy," Proceedings of the Institution of Civil Engineers-Construction Materials 168(5), 219-231. DOI: 10.1680/coma.13.00021

Hadi, Y. S., Nawawi, D. S., Abdillah, I. B., Pari, G., and Pari, R. (2021). "Evaluation of discoloration and subterranean termite resistance of four furfurylated tropical wood species after one-year outdoor exposure," Forests 12(7), 900. DOI: 10.3390/f12070900

Hill, C. A. S. (2006). Wood Modification Chemical, Thermal and Other Processes, John Wiley \& Sons, Hoboken, NJ, USA.

ISO 13061-2 (2014). "Physical and mechanical properties of wood - Test methods for small clear wood specimens - Part 2: Determination of density for physical and mechanical tests," International Organization for Standardization, Geneva, Switzerland.

ISO 13061-3 (2014). "Physical and mechanical properties of wood - Test methods for small clear wood specimens - Part 3: Determination of ultimate strength in static bending," International Organization for Standardization, Geneva, Switzerland.

ISO 13061-10 (2014). "Physical and mechanical properties of wood - Test methods for small clear wood specimens - Part 10: Determination of impact bending strength," International Organization for Standardization, Geneva, Switzerland.

ISO 13061-12 (2014). "Physical and mechanical properties of wood - Test methods for small clear wood specimens - Part 12: Determination of static hardness," International Organization for Standardization, Geneva, Switzerland.

ISO 13061-13 (2016). "Physical and mechanical properties of wood - Test methods for small clear wood specimens - Part 13: Determination of radial and tangential shrinkage," International Organization for Standardization, Geneva, Switzerland.

ISO 13061-17 (2014). "Physical and mechanical properties of wood - Test methods for small clear wood specimens - Part 17: Determination of ultimate stress in 
compression parallel to grain," International Organization for Standardization, Geneva, Switzerland.

Jelle, B. P., Rüther, P., and Hovde, P. J. (2012). "Investigations of accelerated climate aged wood substrates by Fourier transform infrared material characterization," Advances in Materials Science and Engineering 2012(1), Article ID 827471. DOI: $10.1155 / 2012 / 827471$

Keyoumu, A., McDonald, A. G., and Gorman, T. (2007). "Ponderosa pine wood enhancement by resin treatment," in: The Third European Conference on Wood Modification, Cardiff, Wales, pp. 267-270.

Khandarkar, K. M., Ahmed, M., and Meshram, J. S. (2014). "Indian natural zeolites catalyzed urea furfural green polymerization," International Journal of Innovative Research in Science, Engineering and Technology 3(5), 12079-12087. DOI: 10.1.1.1059.5596

Lande, S., Westin, M., and Schneider, M. (2008). "Development of modified wood products based on furan chemistry," Molecular Crystals and Liquid Crystals 484(1), 367-378. DOI: 10.1080/15421400801901456

Lande, S., Westin, M., and Schneider, M. (2004). "Properties of furfurylated wood," Scandinavian Journal of Forest Research 19(5), 22-30. DOI: 10.1080/0282758041001915

Larnøy, E., Lande, S., and Vestøl, G. I. (2008). "Variations of furfuryl alcohol and wolmanit CX-8 treatability of pine sapwood within and between trees," in: International Research Group on Wood Preservation, IRG/WP Document 08-40421, Istanbul, Turkey.

Li, W., Wang, H., Ren, D., Yu, Y., and Yu, Y. (2015). "Wood modification with furfuryl alcohol catalysed by a new composite acidic catalyst," Wood Science and Technology 49(4), 845-856. DOI: 10.1007/s00226-015-0721-0

Li, W., Zhang, X. X., Yu, Z., Yu, Y. S., and Yu, Y. (2017). "Determining the curing parameters of furfuryl alcohol for wood modification by nanoindentation," European Journal of Wood and Wood Products 75(1), 81-87. DOI: 10.1007/s00107-016-1057-7

Li, Y. (2011). "Wood-polymer composites," in: Advances in Composite Materials Analysis of Natural and Man-Made Materials, P. Tesinova (ed.), IntechOpen, London, UK, pp. 229-284. DOI: 10.5772/17579

Li, W., Liu, M., Wang, H., and Yu, Y. (2020). "Fabrication of highly stable and durable furfurylated wood materials. Part II: The multi-scale distribution of furfuryl alcohol (FA) resin in wood," Holzforschung 74(12), 1147-1155. DOI: 10.1515/hf-2019-0287

Li, W., Ren, D., Zhang, X., Wang, H., and Yu, Y. (2016). "The furfurylation of wood: A nanomechanical study of modified wood cells," BioResources 11(2), 3614-3625.

DOI: 10.15376/biores.11.2.3614-3625

Lionetto, F., Del Sole, R., Cannoletta, D., Vasapollo, G., and Maffezzoli, A. (2012). "Monitoring wood degradation during weathering by cellulose crystallinity," Materials 5(10), 1910-1922. DOI: 10.3390/ma5101910

Mai, C., and Militz, H. (2004). "Modification of wood with silicon compounds. Inorganic silicon compounds and sol-gel systems: A review," Wood Science and Technology 37(5), 339-348. DOI: 10.1007/s00226-003-0205-5

Mantanis, G. I. (2017). "Chemical modification of wood by acetylation or furfurylation: A review of the present scaled-up technologies," BioResources 12(2), 4478-4489. DOI: 10.15376/biores.12.2.Mantanis 
Mantanis, G. I., and Lykidis, C. (2015). "Evaluation of weathering of furfurylated wood decks after a 3-year outdoor exposure in Greece," Drvna Industrija 66(2), 115-122. DOI: $10.5552 /$ drind.2015.1425

Mirshokraie, S. A., Larie J., Mostaghni F., and Abdulkhani, A. (2014). "Analysis of photodegraded lignin and lignin model compounds by ATR-FTIR spectroscopy," Iranian Journal of Wood and Paper Science Research 29(3), 343-353. DOI: 10.22092/ijwpr.2014.6185 (In Persian)

Novotny, E. E., and Johnson, W. W. (1931). "Furfural-urea resin and process of making the same," U. S. Patent No. 1827824A.

Pandey, K. K. (2005). "Study of the effect of photo-irradiation on the surface chemistry of wood," Polymer Degradation and Stability 90(1), 9-20. DOI: 10.1016/j.polymdegradstab.2005.02.009

Pizzi, A. (2016). “Wood products and green chemistry," Annals of Forest Science 73(1), 185-203. DOI: 10.1007/s13595-014-0448-3

Pizzi, A., and Scharfetter, H. O. (1978). "The chemistry and development of tannin-based adhesives for exterior plywood," Journal of Applied Polymer Science 22(6), 1745 1761. DOI: 10.1002/app.1978.070220623

Reed, N. R., and Kwok, E. S. C. (2014). "Furfural," in: Encyclopedia of Toxicology, 685688. DOI: $10.1016 / \mathrm{b} 978-0-12-386454-3$.

Reinprecht, L. (2016). Wood Deterioration, Protection and Maintenance, John Wiley \& Sons, Hoboken, NJ, USA. DOI: 10.1002/9781119106500

Roux, M. L., and Podgorski, L. (2000). "The advantages of having in the future a European accelerated weathering test for wood finishes," Surface Coatings International 83(8), Article Number 399. DOI: 10.1007/BF02692754

Sabeti Fard, S. H., Farhangi, R., and Foroughi Rad, A. (2014). "Removal of furfural coke using antioxidant compounds in oil refineries," in: Second International Conference on Oil, Gas and Petrochemicals, Shahid Beheshti University, Tehran, Iran, pp. 1-5. (In Persian)

Sandberg, D. (1999). "Weathering of radial and tangential wood surfaces of pine and spruce," Holzforschung 53(4), 355-364. DOI: 10.1515/HF.1999.059

Schneider, C. A., Rasband, W. S., and Eliceiri, K. W. (2012). "NIH Image to ImageJ: 25 years of image analysis," Nature Methods 9(7), 671-675. DOI: 10.1038/nmeth.2089

Schneider, M. H., and Phillips, J. G. (2007a). "High weight percent gain (WPG) furfuralurea modification of wood," U. S. Patent No. 20090004495 A1.

Schneider, M. H., and Phillips, J. G. (2007b). "Waterborne furfural-urea modification of wood," U. S. Patent No. 20090005504A1.

Sejati, P. S., Imbert, A., Gérardin-Charbonnier, C., Dumarçay, S., Fredon, E., Masson, E, Nandika, D., Priadi, T., and Gérardin, P. (2017). "Tartaric acid catalyzed furfurylation of beech wood," Wood Science and Technology 51(2), 379-394. DOI: 10.1007/s00226-016-0871-8

Shen, X., Jiang, P., Guo, D., Li, G., Chu, F., and Yang, S. (2021). "Effect of furfurylation on hierarchical porous structure of poplar wood," Polymers 13(1), 32. DOI: 10.3390/polym 13010032

Talaei, A., Zare, M., and Abdolzadeh, H. (2016). "Effect furfurylation on physical properties and surface quality of two species of beech and fir," Iranian Journal of Wood and Paper Industries 7(3), 400-411. (In Persian) 
Temiz, A., Terziev, N., Eikenes, M., and Hafren, J. (2007). "Effect of accelerated weathering on surface chemistry of modified wood," Applied Surface Science 253(12), 5355-5362. DOI: 10.1016/j.apsusc.2006.12.005

Thygesen, L. G., Barsberg, S., and Venås, T. M. (2010). "The fluorescence characteristics of furfurylated wood studied by fluorescence spectroscopy and confocal laser scanning microscopy," Wood Science and Technology 44(1), 51-65. DOI: $10.1007 / \mathrm{s} 00226-009-0255-4$

Venås, T. M., and Rinnan, Å. (2008). "Determination of weight percent gain in solid wood modified with in situ cured furfuryl alcohol by near-infrared reflectance spectroscopy," Chemometrics and Intelligent Laboratory Systems 92(2), 125-130. DOI: 10.1016/j.chemolab.2008.02.002

Zeitsch, K. J. (2000). The Chemistry and Technology of Furfural and its Many Byproducts, Elsevier. DOI: 10.1016/S0167-7675(00)80028-7

Article submitted: May 23, 2021; Peer review completed: August 2, 2021; Revised version received and accepted: September 3, 2021; Published: September 9, 2021.

DOI: $10.15376 /$ biores.16.4.7139-7160 